6. Kennedy JW, Ritchie [L, Davis KB, Fritz JK. Western Washington randomized trial of intracoronary streptokinase in acute myocardial infarction. $N$ Fingl I Med 1983;309:1477-1482.

7. Schuler G, Schwarz F, Hofmann M, Mehmel H, Manthey J, Maurer W, Rauch B, Herrmann HJ, Kubler W. Thrombolysis in acute myocardial infarction using intracoronary streptokinase: assessment by thallium-201 scintigraphy. Circulation 1982;66:658-664.

8. Schroder R, Bianituu G, von Leitner $\mathrm{LK}$, Linderer T, Bruggemann T, Heitz ], Vohringer HF, Wegscheider K. Intravenous short-term infusion of streptoki nase in acute myocardial infarction. Circulation 1983;67:536-548.

9. Neuhaus KL, Tebbe V, Sauer G, Kreuzer H, Kostering H. High dose intravenous streptokinase in acute myocardial infarction. Clin Cardio 1983:6:426-434.

10. Spann JF, Sherry S, Carabello BA, Mann RH, McCann WD, Gault JH Gentzler RD, Rosenberg KM, Maurer AH, Denenberg BS, Warner HF, Rubin RN, Malmud LS, Comerota A. High-dose, brief intravenous streptokinase early in acute myocardial infarction. Am Heart I 1982;104:939-945.

11. Reduto LA, Smalling RW, Freund GC, Gould KL. Intracoronary infusion of streptokinase in patients with acute myocardial infarction: effects of reperfusion on left ventricular performance. Am J Cardiol 1981;48:403-409.

12. Simoons ML, Wijns W, Balakumaran $K$, Serruys PW, van den Brand $M$, Fioretti P, Reiber JHC, Lie P, Hugenholtz PG. The effect of intracoronary thrombolysis with streptokinase on myocardial thallium distribution and left ventricular function assessed by blood-pool scintigraphy. Eur Heart I 1982;3;433-440.

13. Hooghoudt TEH, Serruys PW, Reiber IMC, Slager CI, van den Brand M, Hugenholtz PG. The effect of recanalization of the occluded coronary artery in acute myocardial infarction on left ventricular function. Eur Heart ) 1982;3:416-421.

14. Spann JF, Sherry S, Carabello BA, Denenberg BS, Mann RH, McCann WD, Gault JH, Gentzler RD, Belber AD, Maurer AH, Cooper EM. Coronary thrombolysis by intravenous streptokinase in acute myocardial infarction acute and follow-up studies. Am J Cardiol 1984:53:655-661.

15. Smalling RW Fucntos $S$, Avithews MW, Freund GC, Hicks $\mathrm{CH}$, Reduto LA, Walker WE, Sterling RP, Gould KL. Sustained improvernent in left ventricular function and mortality by intracoronary streptokinase administration during evolving myocardial infarction. Circulation 1983;68:131-138.

16. Rentrop P, Blanke $H$, Karsch KR, Rutsch W, Schartl M, Merx W, Dorr R, Mathey D, Kuck K. Changes in left ventricular function after intracoronary streptokinase infusion in clinically evolving myocardial infarction. Am Heart | 1981;102:1188-1193.

17. Schroder R. Systemic verses intracoronary streptokinase infusion in the treatment of acute myocardial infarction. IACC 1983;1:1254-1261.

18. Serruys PW, Wijns $W$, van den Brand $M$, Ribeiro V, Fioretti $P$, Simoons ML, Kooijman CJ, Reiber JHC. Hugenholtz PG. Is transluminal coronary angioplasty mandatory after successful thrombolysis? Br Heart I 1983;50:257-265.

19. Merx W, Dorr R, Rentrop P. Blanke H, Karsch KR. Mathey DG, Kremer P, Rutsch W, Schmutzler H. Evaluation of the effectiveness of intracoronary streptokinase infusion in acute myocardial infarction: postprocedure management and hospital course in 204 patients. Am Heart I 1981;102:1181-1187 20. DeWood MA, Spores J, Hensley GR, Simpson CS, Eugster GS, Sutherland $\mathrm{KI}$, Grunwald RP. Shields JP. Coronary arteriographic findings in acute transmural myocardial infarction. Circulation 1983;68:suppl I:I-39-I-49.

\section{Demonstration of the "No-Reflow" Phenomenon by Digital Coronary Arteriography}

\author{
ERIC R. BATES, MD \\ MARK J. KRELL, MD \\ EDWARD N. DEAN, MD \\ WILUAM W. O'NEIL, MD \\ ROBERT A. VOGEL, MD
}

ncomplete return of normal blood flow in the reperfusion period after prolonged ischemia has been termed the "no-reflow" phenomenon. ${ }^{1}$ This has only recently been demonstrated in humans by intracoronary thallium-201 scintigraphy. ${ }^{2}$ In this report, we demonstrate the "no-reflow" phenomenon in a patient by digital coronary arteriography.

A previously healthy 58 -year-old woman with 3 hours of anginal chest pain associated with precordial ST-segment elevation was treated with 1.5 million $U$ of intravenous streptokinase. Cardiac catheterization was performed 5 hours after the onset of symptoms. Coronary arteriography showed widely patent coronary arteries. The left ventricular ejection fraction was $39 \%$, with regional akinesia in the distribution of the left anterior descending coronary artery (Fig. 1). The hospital course was unremarkable. Peak creatine kinase level was 849 IU. Repeat cardiac catheteriza-

From the Division of Cardiology, University of Michigan Hospitals, Ann Arbor, Michigan. This work was supported in part by research funds from the Veterans Administration. Manuscript received April 22, 1985; revised manuscript received June 18, 1985, accepted June 21, 1985. tion was done 9 days later. The left ventricular ejection fraction was $58 \%$, with apical akinesia (Fig. 1). Coronary arteriographic findings were again normal, and ergonovine $(0.3 \mathrm{mg})$ provocation was negative. Uncertain whether the myocardial infarction was a

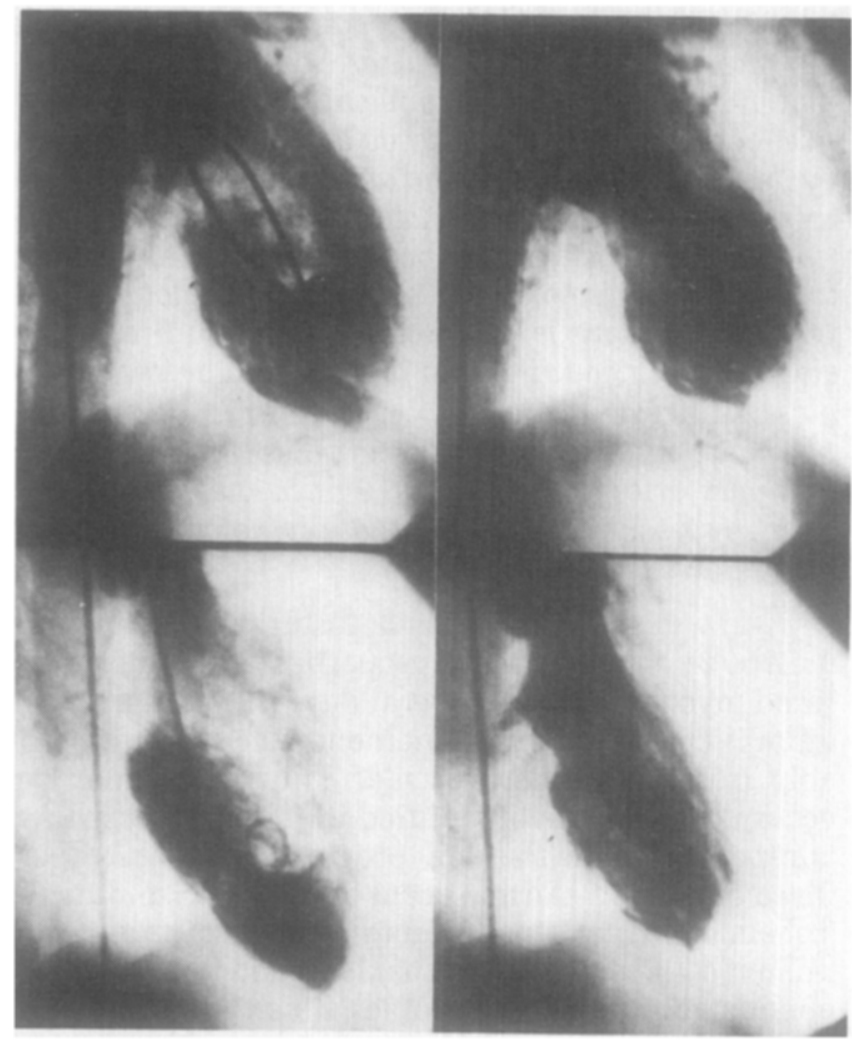

FIGURE 1. Left ventriculograms in the right antertor oblique projections immediately after intervention (top) and 9 days later (bottom). End-diastolic (left) and end-systollc (right) frames are shown. Left ventricular function is markedly improved at the second study. 


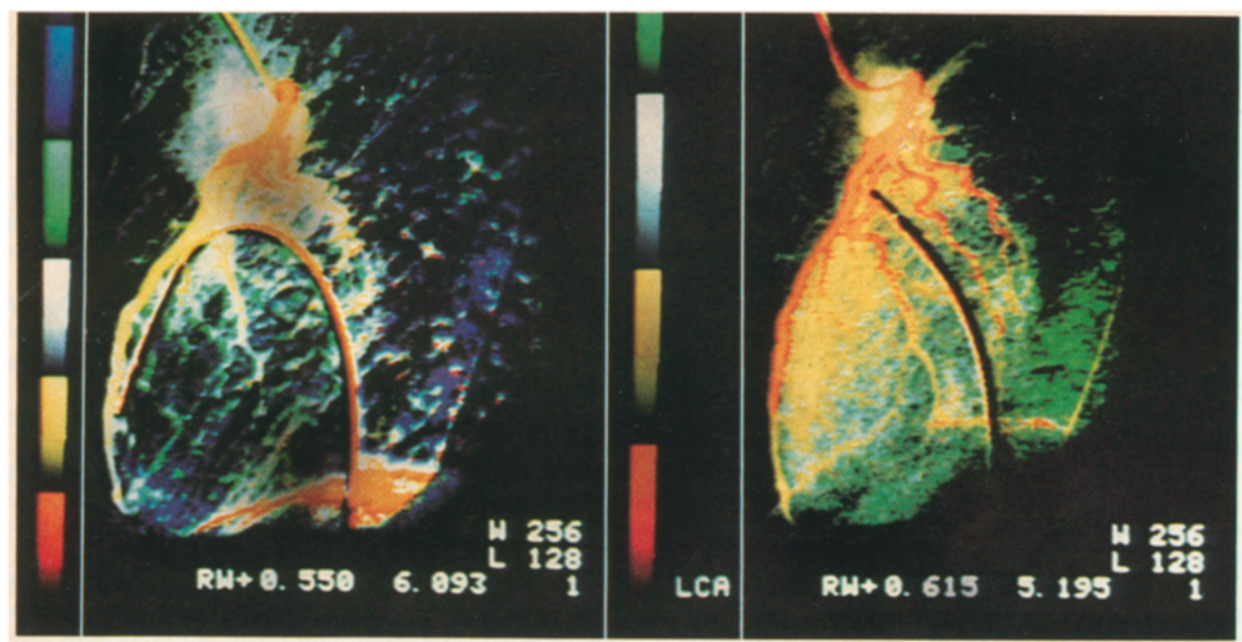

FIGURE 2. Contrast medium appearance pictures of the lelt coronary artery in the left anterior obllque projection acuitely after Infervention (Ieft) and 9 days later (right), with a 3.6-fold increase in relative regional blood flow in the left anterior descending perfusion bed.

result of coronary emboli or spasm, we empirically treated the patient for both with chronic aspirin, dipyridamole and diltiazem therapy.

Digital coronary arteriography of the left coronary artery was performed during both catheterization procedures. ${ }^{3}$ Contrast medium was power injected and synchronized to the $R$ wave of the electrocardiogram at a rate of $4 \mathrm{ml} / \mathrm{s}$ for a total of $7 \mathrm{ml}$. One gated end-diastolic image per cardiac cycle was acquired. Pictures of contrast medium appearance were then generated by mask mode subtraction (Fig. 2). The intensity of each pixel corresponds to the maximal contrast density reached during each acquisition, while the appearance time of contrast in the pixel is colormodulated, with a different color assigned to each post-contrast injection cardiac cycle (red for the first cycle, yellow for the second, and so on]. Because contrast density is directly related to volume of distribution in the myocardium and flow is inversely related to appearance time, digital estimation of relative coronary blood flow is calculated as the contrast density/appearance time ratio in a defined area of interest. During the acute study, the contrast density/appearance time ratio for the left anterior descending coronary artery was 0.07 and 9 days later, it was 0.25 . This represents 3.6-fold increase, in relative regional blood flow.

A few minutes of ischemia disturbs the structural, metabolic and functional properties of reversibly injured myocardium for several days (stunned myocardium). ${ }^{4}$ The no-reflow phenomenon, however, is probably caused by microvascular injury and does not occur until irreversibly injured ischemic myocardium is reperfused. ${ }^{5}$ In the dog, progressive loss of reperfused blood flow starts to occur only after 25 minutes of ischemia, but is virtually complete after 60 minutes of ischemia. ${ }^{6}$ Postulated mechanisms for the no-reflow phenomenon include endothelial cell swelling, perivascular edema, capillary plugging by erythrocytes or leukocytes, and small vessel spasm. ${ }^{1,7}$

In the report by Schoffer et al, ${ }^{2}$ the acute residual thallium-201 defect representative of the no-reflow phenomenon was unchanged 2 to 4 weeks after throm. bolysis. The contrast medium appearance picture gen- erated by our digital technique, however, demonstrated a diffuse decrease in regional flow, which improved 9 days after infarction. These discordant findings are probably reconciled by recent data published by Kloner and Alker ${ }^{7}$ in a dog model. They describe areas of very low myocardial blood flow after reperfusion associated with anatomic perfusion defects, microvascular damage, and infarcted tissue consistent with no reflow. In addition, however, areas of low reflow detected by microspheres were present in the ischemic subepicardium, which did not have microvascular damage or anatomic perfusion defects. They postulated that low reflow was a result of the lower oxygen demand of the stunned myocardium.

The marked improvement in ventricular function and the low creatine kinase level in our patient suggest early reperfusion, a limited apical infarction, and a large area of stunned myocardium which recovered normal function. Flow data from our digital radiographic technique during reperfusion are probably more consistent with microsphere flow data showing reduced flow than with thallium-201 perfusion data, which reflect only lowest flow owing to myocardial infarction. Application of digital and scintigraphic techniques should allow further investigation of stunned myocardium and the no-reflow phenomenon in humans.

\section{References}

1. Kloner RA, Ganote CE, Jennings RB. The "no-reflow" phenomenon after temporary coronary occlusion in the dog. I Clin Invest 1974;54:1496-1508. 2. Schoffer I. Montz R, Mathey DG. Scintigraphic evidence of the "no-reflow" phenomenon in tuman beings after coronary thrombolysis. IACC 1985;5:593-598.

3. Hodgson JM, LeGrand V, Bates ER, Mancini GBJ, Aueron FM, O'Neill WW, Simon SB, Beauman GI, LeFree MT, Vogel RA. Validation in dogs of a rapid angiographic technique to measure relative coronary blood flow during routine cardiac catheterization. Am J Cardiol 1985;55:188-193.

4. Braunwald E, Kloner RA. The stunned myocardium: prolonged postischemic ventricular dysfunction. Circulation 1982;66:1146-1149.

5. Kloner RA, Rude RE, Carlson N, Maroko PR, DeBoer LWV, Braunwald E. Ulirustructural evidence of microvascular damage and myocardial cell injury after coronary artery occlusion: which comes first? Circulation 1980; 62:945-952.

6. Gavin JB, Seelye RN, Nevalainen T], Arminger LC. The effect of ischaemia on the function and fine structure of the microvasculature of myocardium. Pathology 1978;10:103-111.

7. Kloner RA, Alker KI. The effect of streptolinase on intramyocardial bemorrbage, infarct size, and the no reflow phenomenon during coronary reperfusion. Girculation 1984;70:513-521. 